\section{البصيرة: مبلة الصراهات الإهلاهية AL-BASHIRAH: JOURNAL OF ISLAMIC STUIDES \\ Vol. 1 No. 1(2020): 180-199}

Website: https://journal.stiba.ac.id

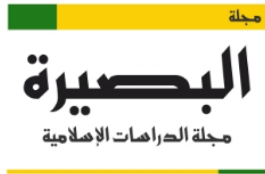

AL-BASHIRAH

\title{
أوامر في سورة النساء المتعلقة بأحكام الأسرة; دراسة تطبيقية
}

\author{
أول رفاعي \\ المعهد العالي للدراسات الإسلامية والعربية بمكسر \\ البريد الإلكتروين:awalrifai@stiba.ac.id \\ أسامة مامنج \\ جامعة القصيم بالقصيم

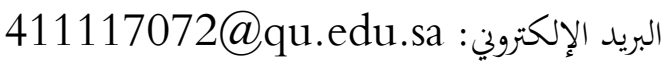

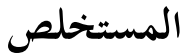

سورة النساء إحدى السور المدنية الطويلة وهي سورة مليئة بالأحكام التشريعية التي تنظم الشئون الداخلية والخارجية للمسلمين, وقد تميزت

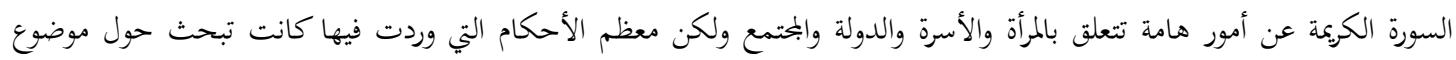

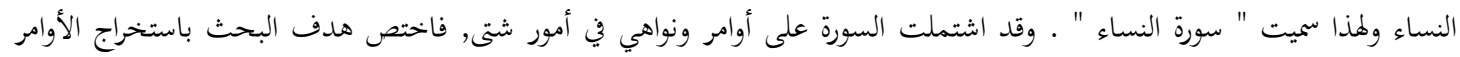

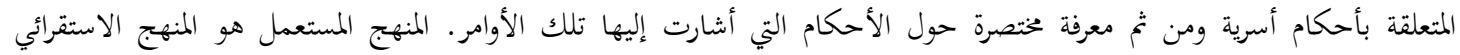

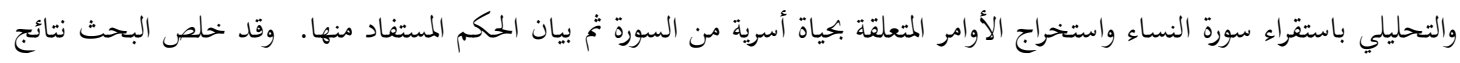

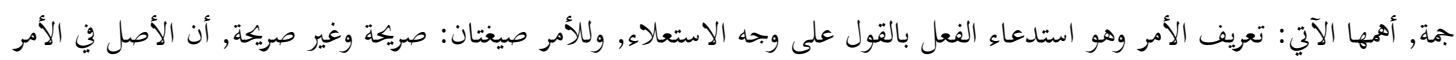
للوجوب وقد يكون للندب والإباحة لوجود الصارف عن الوجوب. أما عدد الأوامر المتعلقة بأحكام الأسرة في السورة V ا أمرا. الكلمات الدالة: أحكام, أسرة, أوامر , سورة النساء.
\end{abstract}

\section{Awāmir (Commands) in Surat al-Nisā' Relating to Domestic Life: An Empirical Study}

\author{
Awal Rifai \\ Email: awalrifai@stiba.ac.id \\ Usamah Maming \\ Qassim University, Saudi Arabia \\ Email:411117072@qu.edu.sa
}

Sekolah Tinggi Ilmu Islam dan Bahasa Arab (STIBA) Makassar, Indonesia

\begin{abstract}
Surah An-Nisa is one of the longest madaniah surah, and is one full of provisions of sharia laws that govern all matters both internal and external ones for Muslims. Among the prominence of this noble surah is that it tells a lot about important things related to women, household, family, country, and social life. In this surah, there are commands and prohibitions in various matters. The purpose of this study was to extract imperative sentences related to family life and then briefly identify the rules that
\end{abstract}

$$
\text { أول رفاعي ,أسامة مامنج .أوامر في سورة النساء المثعلقة بأحكام الأسرة; دراسة تطبيقية }
$$




\section{البحسيرة: مبلة الصراهات الإهلاهية AL-BASHIRAH: JOURNAL OF ISLAMIC STUIDES \\ Vol. 1 No. 1(2020): 180-199}

Website: https://journal.stiba.ac.id

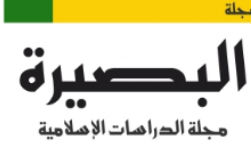

AL-BASHIRAH

became the base for these commands. The researcher employed an inductive and analytical approach by extrapolating Surah Al-Nisa, taking imperative sentences related to family life, and explaining the law which is concluded from it. Researcher finds, among the most important of the most important ones are as follows: understanding the meaning of al-amr (command) which is a request to do something in the form of superiority. There are two types of amr: direct and indirect. The number of amr related to the family in the surah is seventeen.

Keywords: Rules, family, commands, Surah An-Nisa.

المقدمة

الحمد لله رب العالمين وبه نستعين على أمور الدنيا والدين والصلاة والسلام على نبينا محمد وعلى آله وأصحابه ومن تبعهم بإحسان إلى يوم الدين. أشهد ألا إله إلا الله وأشهد أن محمد رسول الله, أما بعد ولد وله

في سورة النساء أحكام هامة بالنسبة إلى كل مسلم فلابد من معرفتها وأكثر ما تكون في

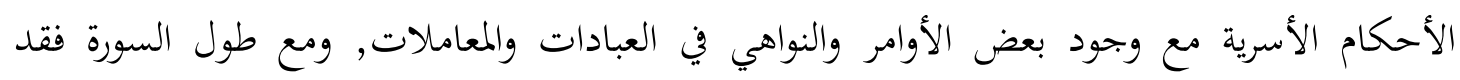
يصعب على التالي والقارئ للقرآن استخراج الأحكام منها وبالتالي يحتاج في استخراجها إلى الخلفية السابقة في دراسة أصول الفقه خحاصة ما يتعلق بدلالة الألفاظ حيث تنبني منها أحكام تكليفية وخاصة

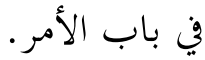

أما المنهج المستعمل في هذا البحث هو المنهج الاستقرائي والتحليلي حيث قام الباحث باستقراء سورة النساء واستخراج الأوامر المتعلقة بحياة أسرية من سورة النساء ثم بين الحكم المستفاد منها بيانا مختصرا. من المستحسن قبل الدخول إلى صلب الموضوع التعرف بالأمر وأنواعه وصيغته كما استبان ذلك فيما يلي: الأمر لغة: ذكر ابن فارس أن مادة الألف والميم والرا ترجع إلى أصول خمسة وهي : 1 . الأم من الأمور, فقولمم هذا أمر رضيته، وأمر لا أرضاه. وفي المثل: " أمر ما أتى بك الك ". ومن

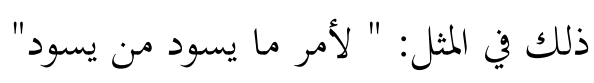

2 . 2 الأمر ضد النهي, قولك افعل كذا. قال الأصمعي: يقال: لي عليك أمرة مطاعة، أي: لي عليك أن آمرك مرة واحدة فتطيعني. قال الكسائي: فلان يؤامر نفسيه، أي: نفس تأمره بشيء ونفس تأمره بآخر. وقال: إنه لأمور بالمعروف وفي عن المنكر، من قوم أمر. ومن هذا الباب الإمرة والإمارة، وصاحبها أمير ومؤمر. قال ابن الأعرابي: أمرت فلانا، أي: جعلته أميرا. وأمرته وآمرته كلهن بمعنى واحد. قال ابن الأعرابي: أمر فلان على قومه: إذا صار أميرا. 


\section{البصيرة: مبلة الصراهات الإهلامية AL-BASSHIRAH: JOURNAL OF ISLAMIC STUIDES \\ Vol. 1 No. 1(2020): 180-199}

Website: https://journal.stiba.ac.id

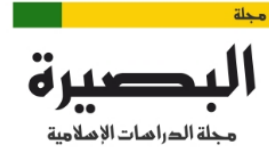

AL-BASHIRAH

ـ 3 الأمر : النماء والبركة, قال الخليل: الأمر النماء والبركة وامرأة أمرة، أي: مباركة على زوجها.

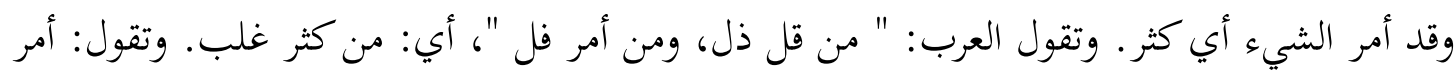

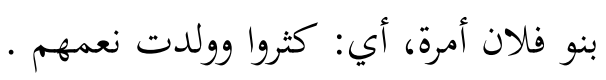

4 4 المعلم والموعد, قال الخليل: الأمارة الموعد. قال العجاج: إلى أمار وأمار مدتي. قال الأصمعي:

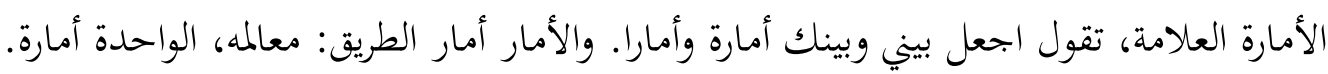
5.

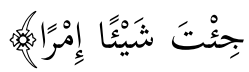

والمراد في بحثنا الحالي هو معنى الأمر الذي هو ضد النهي, لأنه من خطاب الشرع التكليفي, إذ لا

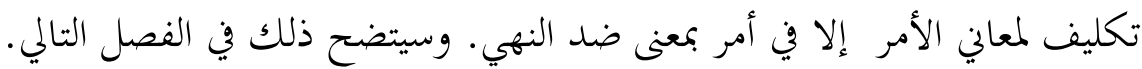

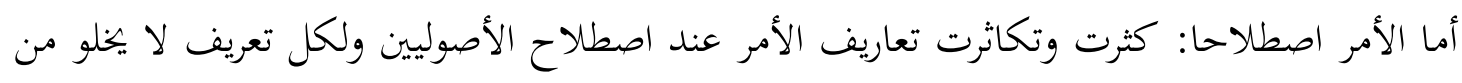

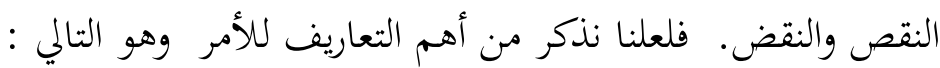

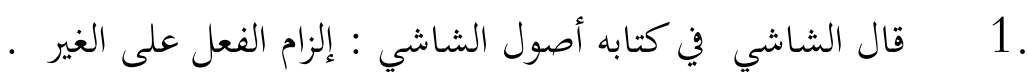

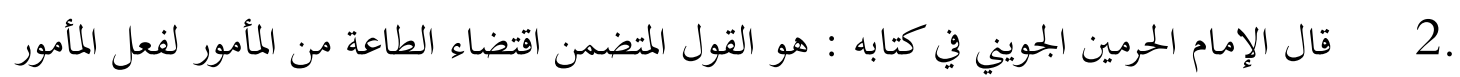
به , وهذا تعريف أبي بكر الباقلاني، واختاره الغزالي وأكثر الأشاعرة .

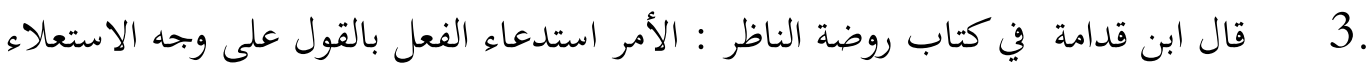

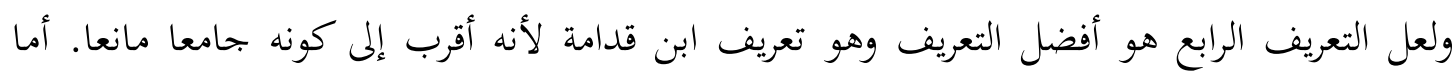

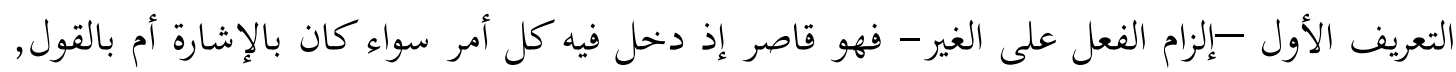
أو على وجه الاستعلاء أو غيره. وأما التعريف الثاني - القول المتضمن اقتضاء الطاعة من المأمور لفعل المأمور به- , قال به ابن قدامة

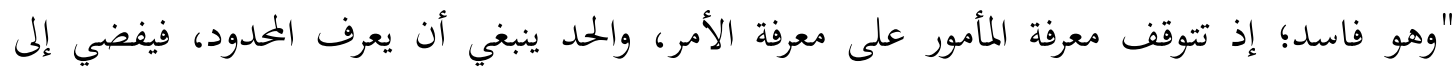

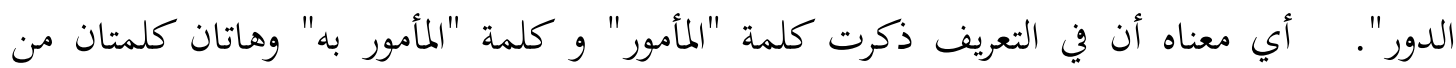

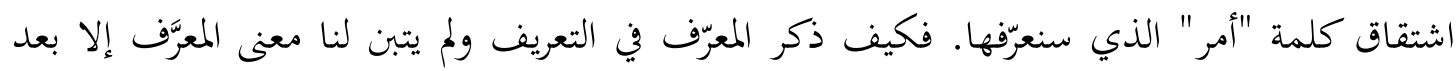

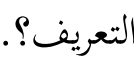

ولذلك, التعريف لابن قدامة من أفضلها لأنه يشمل ماهية الأمر (استدعاء الفعل) وكيفيته (بالقول) وصفته (على وجه الاستعلاء). 


\section{البصيرة: مبلة الصراهات الإهلامية AL-BASHHIRAH: JOURNAL OF ISLAMIC STUIDES \\ Vol. 1 No. 1(2020): 180-199}

Website: https://journal.stiba.ac.id

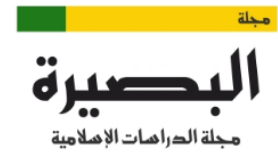

AL-BASHIRAH

اختلف الأصوليون في الأمر هل له صيغة تخصه أم لا؟ (فأما منكرو الكلام النفسي فذهبوا إلى

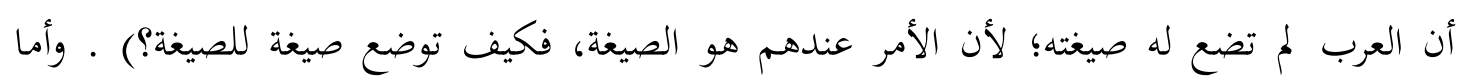
المثتبون لكلام النفس فهم اختلفوا إلى قولين وهما:

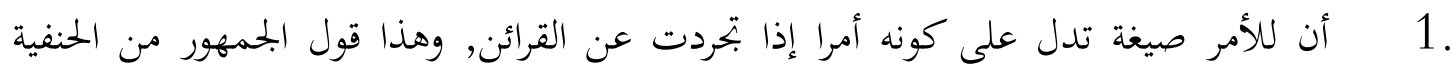

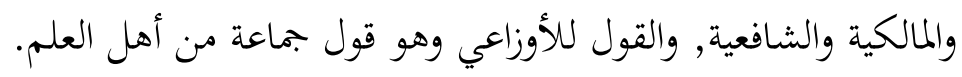
2 2 أن للأمر ليس له صيغة تخصه, وهذا القول نقل من أبي الحسن الأشعري. (بناء على خيالهم: أن الكلام معنى قائم بالنفس) . لعل العمل في هذا البحث هو أن للأمر صيغة تخصه لأن أهل اللغة اتفاقوا على تسمية هذه الصيغة

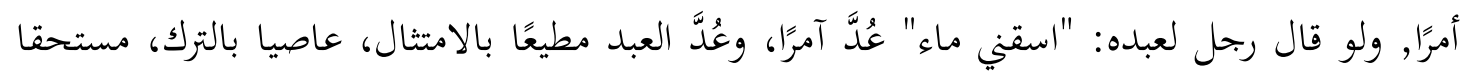
للأدب والعقوبة .

الصيغة للأمر تنقسم إلى قسمين : الصريحة وغير الصريحة, والبيان لكل واحد منهما كالآتي: صيغ الأمر الصريحة 1.

2.

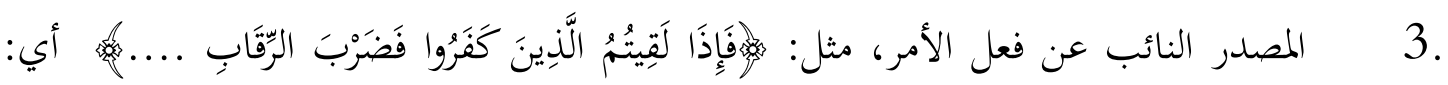
فاضربوا الرقاب.

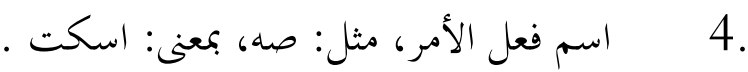

$$
\begin{aligned}
& \text { صيغ الأمر غير الصريحة } \\
& \text { وأما الأوامر غير الصريحة؛ فضروب: }
\end{aligned}
$$

1 . 1.

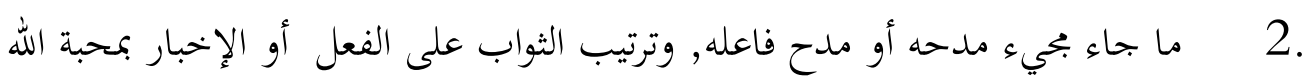

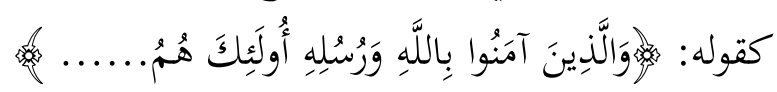

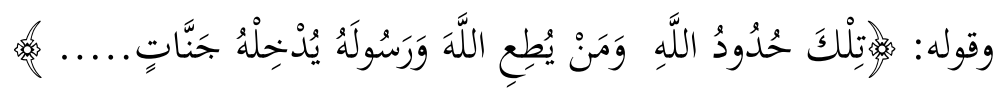

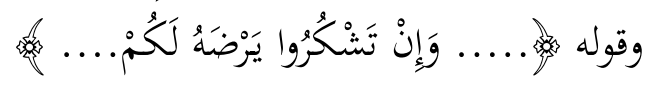
3.

4.

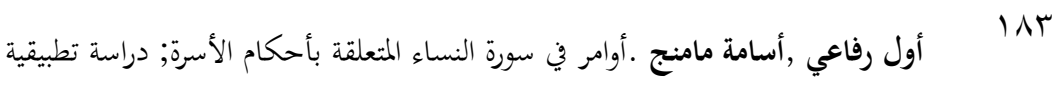




\section{البصيرة: مبلة الصراهات الإهلامية AL-BASHIRAH: JOURNAL OF ISLAMIC STUIDES \\ Vol. 1 No. 1(2020): 180-199}

Website: https://journal.stiba.ac.id

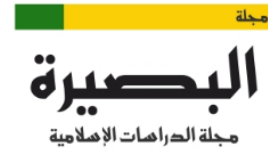

AL-BASHIRAH

وهناك أساليب أخرى يستفاد منها الأمر لم يشتغل الأصوليون بجصرها لصعوبة ضبطها.

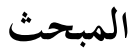

قد اشتملت السورة على أوامر عديدة تتعلق بأحكام الأسرة نسردها فيما يلي:

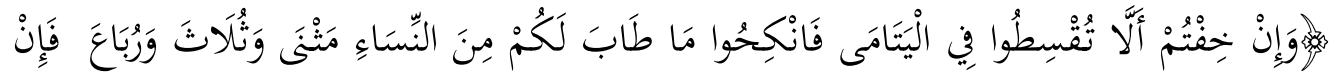

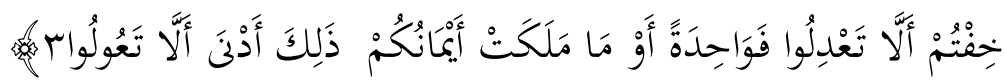

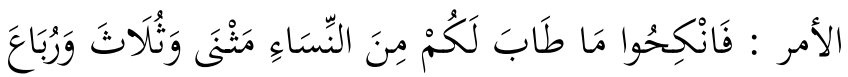

صيغته : صريحة (فعل الأمر)

حكمه : الأصل هو الندب, لكن بحري في النكاح الأحكام الخمسة

الأصل في حكم النكاح هو الندب, لأن الله تعالى حين أمر ب,. علقه على الاستطابة، بقوله

سبحانه: $\}$ فانكحوا ما طاب لكم من النساء\{ والواجب لا يقف على الاستطابة . لكن قد تجري فيه الأحكام الخمسة," فقال قوم: هو مندوب إليه، وهم الجمههور. وقال أهل الظاهر: هو واجب. وقالت المتأخرة من المالكية: هو في حق بعض الناس واجب، وفي حق بعضهم مندوب إليه، وين حق بعضهم مباح، وذلك بحسب ما يخاف على نفسه من العنت ". أما في حكم تعدد الزوجات "اختلف فيها أهل العلم، فمن العلماء من قال: إنه ينبغي أن

يتزوج أكثر من واحدة، ما دام عنده قدرة مالية وطاقة بدنية، بحيث يقوم بواجبهن فإن الأفضل أن يتزوج أكثر؛ تحصيلا لمصالح النكاح، والمفاسد التي تتوقع تنغمر في جانب المصالح، ولأن النبي صلى الله عليه

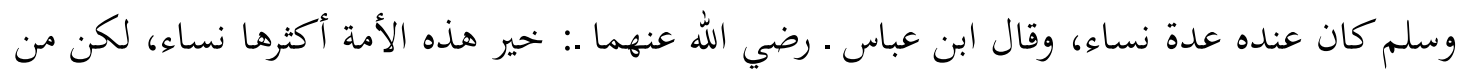
المعلوم أن رسول الله صلى الله عليه وسلم لمج يعدد الزوجات من أجل قضاء الوطر، وإنما من أجل المصلحة العامة؛ حتى يكون له في كل قبيلة صلة، فتكون كل قبائل العرب لما صلة بالنبي صلى الله عليه وسلم؛ لأن المصاهرة قسيم النسب، وعديل النسب.

وذهب بعض أهل العلم إلى أنه يسن أن يقتصر على واحدة، وعلل ذلك بأنه أسلم للذمة من الجحور؛ لأنه إذا تزوج اثنتين أو أكثر فقد لا يستطيع العدل بينهما، ولأنه أقرب إلى منع تشتت الأسرة، فإنه إذا كان له أكثر من امرأة تشتت الأسرة، فيكون أولاد لهذه المرأة، وأولاد لهذه المرأة، وربما يكصل بينهم تنافر بناء على التنافر الذي بين الأمهات، كما هو مشاهد في بعض الأحيان، ولأنه أقرب إلى 


\section{البصيرة: مبلة الدراهات الإهلاهية AL-BASSHIRAH: JOURNAL OF ISLAMIC STUIDES \\ Vol. 1 No. 1(2020): 180-199}

Website: https://journal.stiba.ac.id

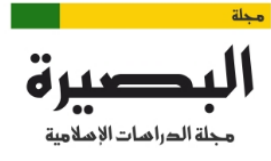

AL-BASHIRAH

القيام بواجبها من النفقة وغيرها، وأهون على المرء من مراعاة العدل، فإن مراعاة العدل أمر عظيم، يحتاج

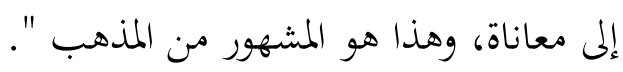

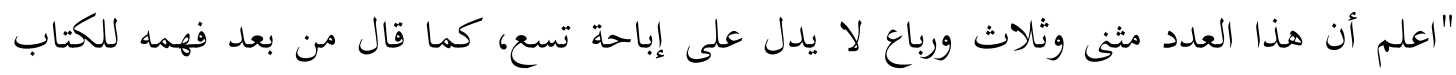

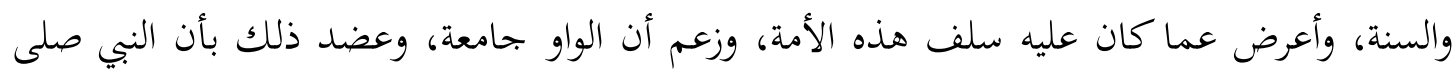

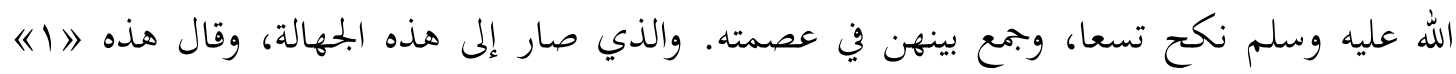

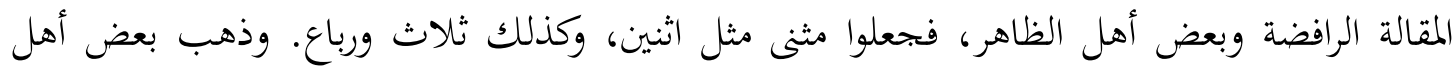

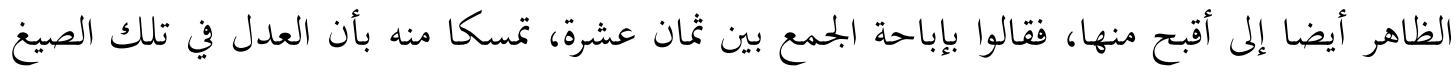

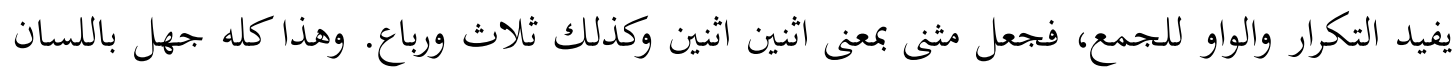

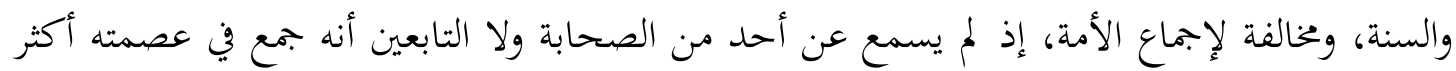
من أربع ". "اتفق المسلمون على جواز نكاح أربعة من النساء معا، وذلك للأحرار من الرجال, أما العبيد فقال

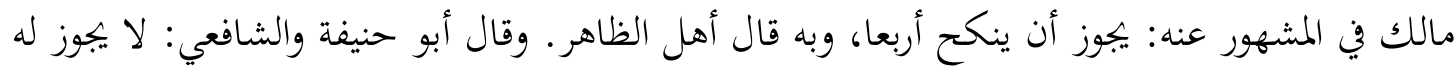
الجمع إلا بين اثنتين فقط. وسبب اختلافهم هل العبودية لما تأثير في إسقاط هذا العدد كما لها تأثير في إسقاط نصف الحدا

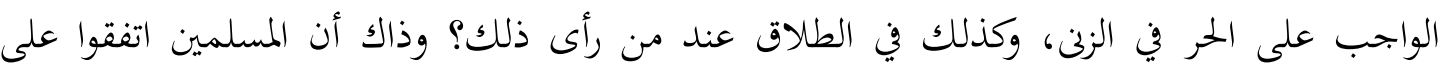

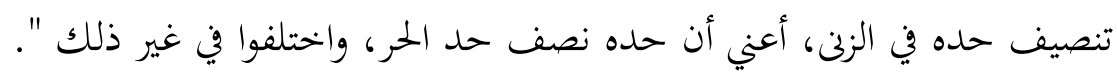

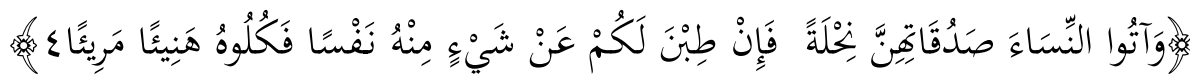
الأمر : وآتوا النساء صدقاتهن نحلة صيغته : صريحة ( فعل الأمر) حكمه واجب

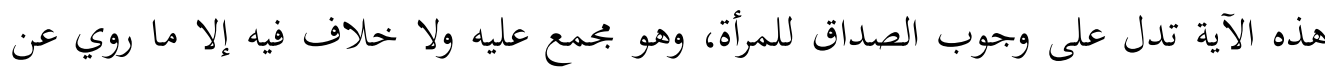

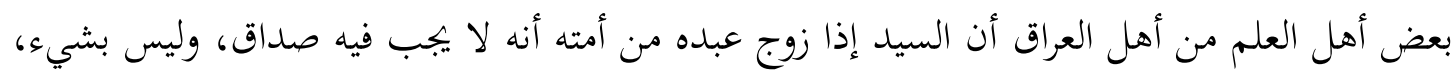
لقوله تعالى: (وآتوا النساء صدقاتهن نحلة) فعام. وقال: (فانكحوهن بإذن أهلهن وآتوهن أجورهن بالمعروف) . الأمر : فكلوه هنيئا مريئا صيغته : صريحة ( فعل الأمر) أول رفاعي ,أسامة مامنج .أوامر في سورة النساء المتعلقة بأحكام الأسرة; دراسة تطبيقية 


\section{البصيرة: مبلة الصراهات الإهلامية AL-BASHIRAH: JOURNAL OF ISLAMIC STUIDES \\ Vol. 1 No. 1(2020): 180-199}

Website: https://journal.stiba.ac.id

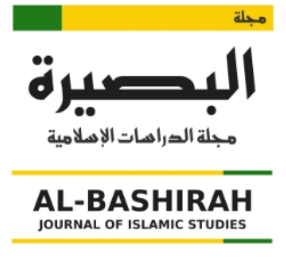

حكمه : إباحة

والصارف من الوجوب إلى الإباحة هو ما "روى ابن عباس عن النبي صلى الله عليه وسلم أنه

سئل عن هذه الآية (فإن طبن لكم عن شيء منه نفسا فكلوه) فقال: (إذا جادت لزوجها بالعطية طائعة غير مكرهة لا يقضي به عليكم سلطان، ولا يؤاخذكم الله تعالى به في الآخرة). " ونفي المآخذة دليل الإباحة. وكذلك هو الأمر بعد الحظر الذي يفيد ما يفيده قبل الحظر , وفي هذه المسالة يفيد الإباحة.

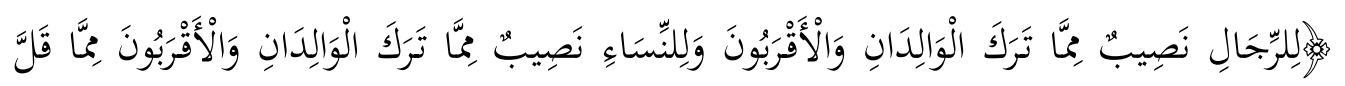

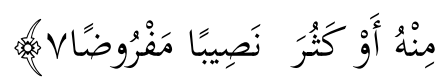

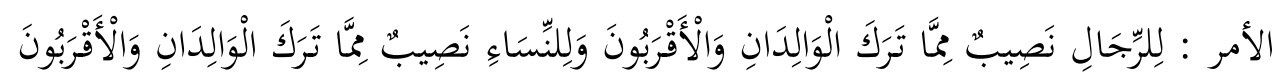

$$
\begin{aligned}
& \text { صيغته : غير صريحة (الخبر) } \\
& \text { حكمه : واجب }
\end{aligned}
$$

في الآية دليل على مشروعية الميراث وأن لكل منهم من الورثة نصيبا فرضه الله لهم. "ولا جرم أن من أهم شرائع الإسلام شرع الميراث، فقد كان العرب في الجاهلية يجعلون أموالهم بالوصية لعظماء القبائل ومن تلحقهم بالانتساب إليهم حسن الأحدوثة، وبحمعهم همم صلات الحلف أو الاعتزاز والود، وكانوا إذا لم يوصوا أو تركوا بعض مالهم بلا وصية يصرف لأبناء الميت الذكور، فإن لم يكن له ذكور فقد حكي أفم يصرفونه إلى عصبته من أخوة وأبناء عم، ولا تعطى بناته شيئا، أما الزوجات فكن فئن موروثات لا وارثات." فنفا الله طريقة إرثهم الظالم وفرض الفرائض في الميراث لتحقيق العدالة وإذهاب الظلم.

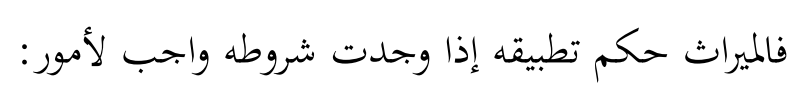

1 أنه تنفيذ لفريضة من فرائض الله، قال الله تعالى لما ذكر ميراث الأصول والفروع:

$$
\text { وأبناؤكم لا تدرون أيهم أقرب لكم نفعا فريضة من الله }
$$

2.

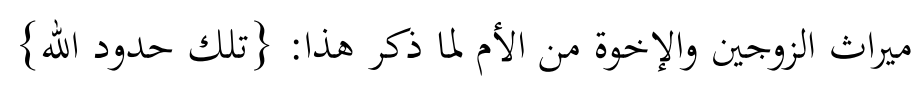

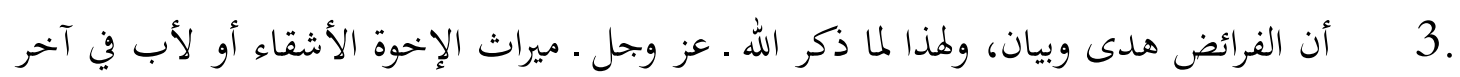

سورة النساء، قال: كيبين الله لكم أن تضلوأ

4.

$$
\text { الحقوق إلى أصحابها من واجبات. }
$$

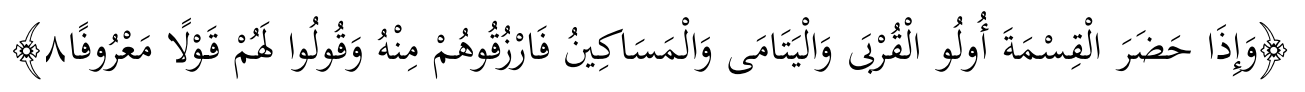




$$
\begin{aligned}
& \text { الأمر : فارزقوهم منه وقولوا لهم قولا معروفا } \\
& \text { الصيغة : صريحة (فعل الأمر) } \\
& \text { حكمه : ندب }
\end{aligned}
$$

بين الله تعالى أن من لم يستحق شيئا إرثا وحضر القسمة، وكان من الأقارب أو اليتامى والفقراء

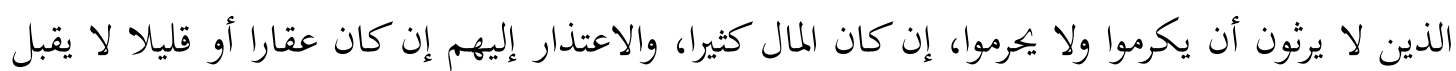
· الرضخ

والأمر في قوله: فارزقوهم منه محمول عند جمهور أهل العلم على الندب من أول الأمر، إذ ليس في

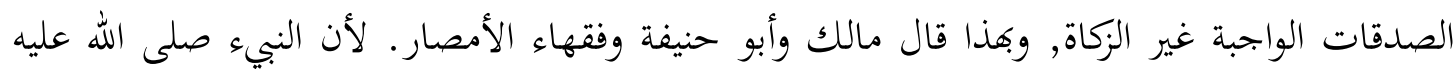

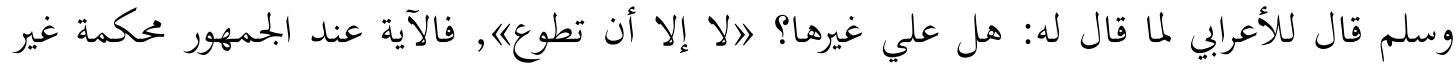
منسوخة.

ومن العلماء من قال بوجوب إعطائهم جميعا وهو قول ابن عباس، وعكرمة، وبحاهد، والزهري،

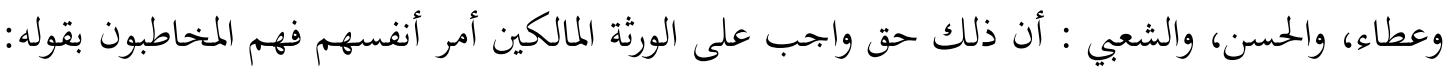

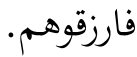

ومنه من قال إن الآية منسوخة, وعن ابن عباس، وأبي موسى الأشعري وسعيد بن المسيب،

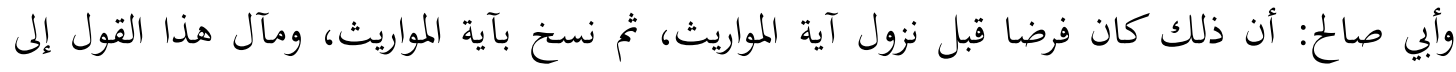
موافقة قول جمهور أهل العلم. والقول الرابع عن سعيد بن جبير: أن الآية في نفس الميراث فقوله: (فارزقوهم منه) هو الميراث

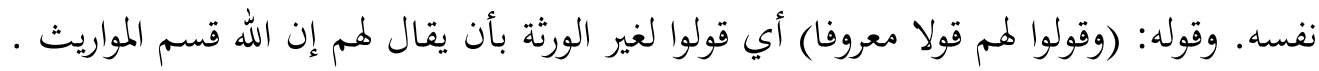

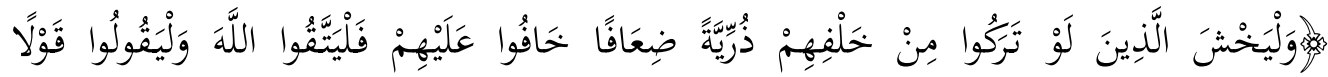
الأمر : وليخش الذين......فليتقوا الله وليقولوا. صيفته : صريحة (الفعل المضارع المقترن بلام الأمر) حكمه : واجب : (2)

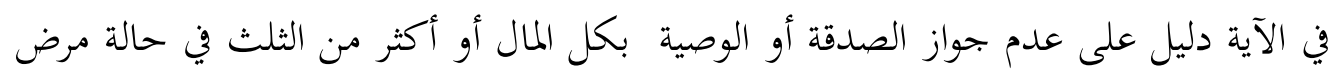

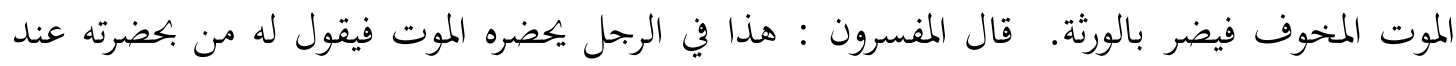

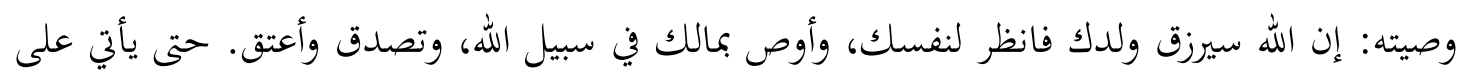
أول رفاعي ,أسامة مامنج أوامر في سورة النساء المتعلقة بأحكام الأسرة; دراسة تطبيقية 


\section{البصيرة: مجلة الصراهات الإهلامية AL-BASSHIRAH: JOURNAL OF ISLAMIC STUIDES \\ Vol. 1 No. 1(2020): 180-199}

Website: https://journal.stiba.ac.id

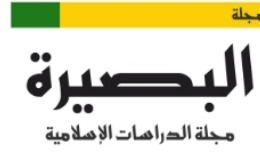

AL-BASHIRAH

عامة ماله أو يستغرقه فيضر ذلك بورثثه، فنهوا عن ذلك. فكأن الآية تقول لهم: (كما تخشون على ورثتكم وذريتكم بعدكم، فكذلك فاخشوا على ورثة غيركم ولا تحملوه على تبذير ماله)، قاله ابن عباس وقتادة والسدي وابن جبير والضحاك وبحاهد. روى سعيد بن جبير عن ابن عباس أنه قال: إذا حضر الرجل الوصية فلا ينبغي أن يقول أوص بمالك فإن الله تعالى رازق ولدك، ولكن يقول قدم لنفسك واترك لولدك، فذلك قوله تعالى: (فليتقوا الله) . ،

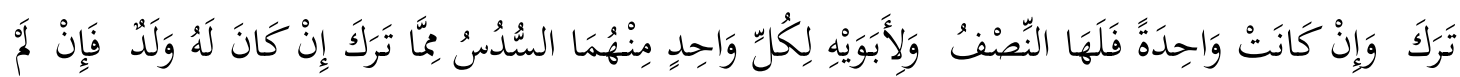

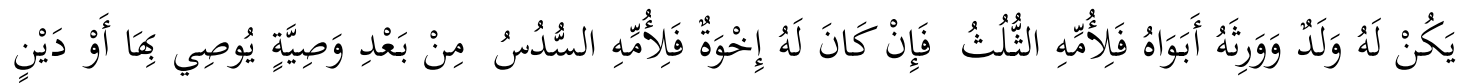

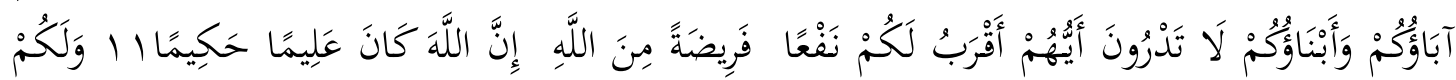

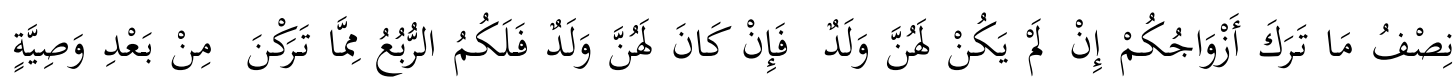

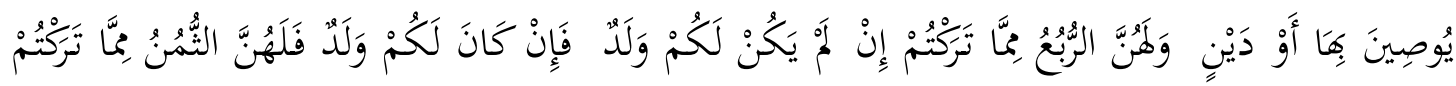

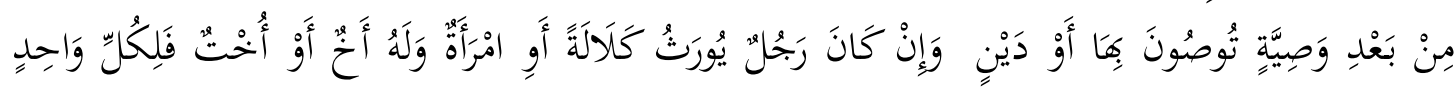

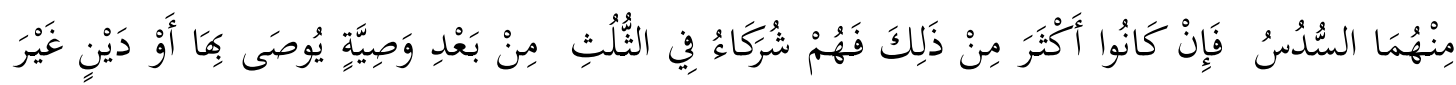

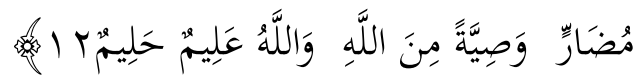
الأوامر في هذه الآية كلها على صيغة غير صريحة (الجملة الحبرية). وهي تتضمن توزيع الميراث إلى لى أصحاب الفروض والتعصيب وذكر شروط استحقاقهم. فهذه الآية منزّلة منزلة البيان والتفصيل لقوله

$$
\text { (للرجال نصيب مما ترك الوالدان والأقربون). }
$$

وحكمه واجب لأن الوصاية -في قوله تعالى (يوصيكم الله)- هي الأمر بما فيه نفع المأمور وفيه اهتمام الآمر لشدة صلاحه، ولذلك سمي ما يعهد به الإنسان، فيما يصنع بأبنائه وبماله وبذاته بعد الموت، وصية .

فأما تفصيل توزيع الميراث فمحله كتب الفقه يطول ذكره هنا .

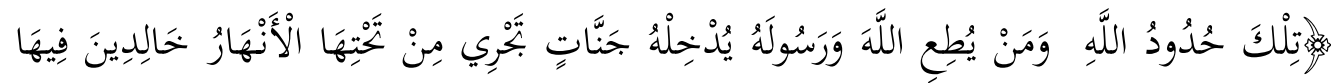

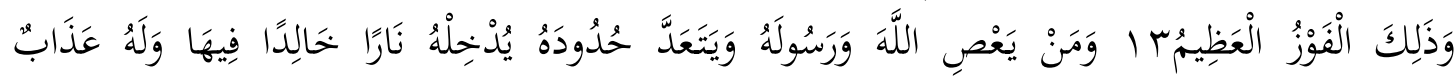

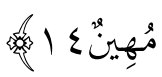

الأمر : تلك حدود الله, ومن يطع الله ورسوله يدخله جنات......إخ صيغته : غير صريحة (ذكر الثواب المترتب على الفعل وذكر العقاب على تركه) أول رفاعي ,أسامة مامنج .أوامر في سورة النساء المتعلقة بأحكام الأسرة; دراسة تطبيقية 


\section{البصيرة: مجلة الصراهات الإهلامية AL-BASHIRAH: JOURNAL OF ISLAMIC STUIDES \\ Vol. 1 No. 1(2020): 180-199}

Website: https://journal.stiba.ac.id

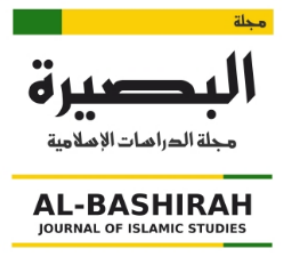

حكمه : واجب

فالتوزيع الرباني في الإرث واجب التطبيق إذ سماه الله حدوده. "والحدود جمع حد، وهو ظرف

المكان الذي يميز عن مكان آخر بحيث يمنع بحاوزه، واستعمل الحدود هنا بحازا في العمل الذي لا تحل مخالفته على طريقة التمثيل ".

"(تلك حدود الله) و (تلك) بمعنى هذه، أي هذه أحكام الله بينها لكم لتعرفوها وتعملوا بها.

(ومن يطع الله ورسوله) في قسمة المواريث فيقر بها ويعمل بها كما أمره الله تعالى (يدخله جنات بتري من تحتها الأفار) جملة في موضع نصب على النعت لجنات. قوله: (ومن يعص الله ورسوله) يريد في قسمة المواريث فلم يقسمها ولم يعمل بها (ويتعد حدوده) أي يخالف أمره (يدخله نارا خالدا فيها)

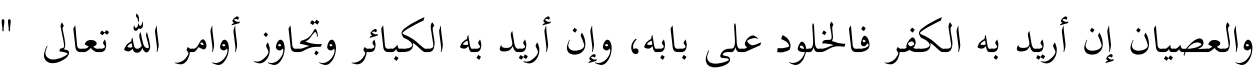

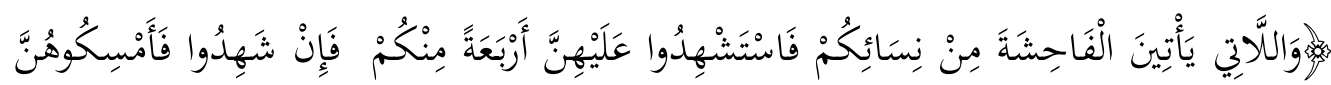

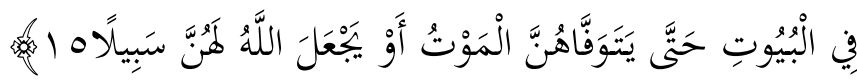

$$
\begin{aligned}
& \text { الأمر : فاستشهدوا عليهن أربعة منكم يكي } \\
& \text { صيغته : صريحة (فعل الأمر) } \\
& \text { حكمه : واجب }
\end{aligned}
$$

وهذه الآية هي الأصل في اشتراط أربعة في الشهادة على الزنى، وقد تقرر ذلك بآية سورة النور.

$$
\text { فالزنا تثبت بأحد الأمرين : الإقرار أو الشهود. }
$$

فالإقرار معروف, وهو أن يقر على نفسه أنه زنا "أربع مرات لحديث ماعز ابن مالك، فإنه اعترف عند

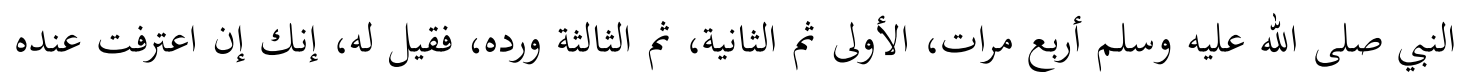

$$
\text { الرابعة رجمك فاعترف فأمر برجمه . }
$$

"وأما ثبوت الزنى بالشهود فإن العلماء اتفقوا على أنه يثبت الزنى بالشهود، وأن العدد المشترط في الشهود أربعة بخلاف سائر الحقوق؛ لقوله تعالى: \}ثم لم يأتوا بأربعة شهداء\{ ، وأن من صفتهم أن أن يكونوا عدولا. وأن من شرط هذه الشهادة أن تكون بمعاينة فرجه في فرجها، وأها تكون بالتصريح لا لا

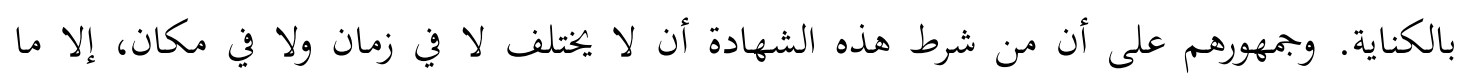
حكي عن أبي حنيفة من مسألة الزوايا المشهورة، وهو أن يشهد كل واحد من الأربعة أنه رآها في ركن من البيت يطؤها غير الركن الذي رآه فيه الآخر ". 


\section{البصيرة: مبلة الصراهات الإهلامية AL-BASHIRAH: JOURNAL OF ISLAMIC STUIDES \\ Vol. 1 No. 1(2020): 180-199}

Website: https://journal.stiba.ac.id

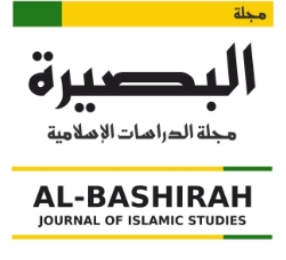

من العلماء من قال أن هذه الآية نزلت في النساء. والمراد بالفاحشة هنا: المساحقة، جعل حدهن الحبس إلى أن يمتن أو يتزوجن. قال: ونزلت والذان يأتياها منكم 》ب شي في أهل اللواط. والتي في النور: في الزانية

$$
\begin{aligned}
& \text { والزاني وخحالف جمهور المفسرين, بناءً على قولمم أنه ليس في القرآن نسخ . } \\
& \text { الأمر : فإن شهدوا فأمسكوهن...... } \\
& \text { صيغته : صريحة (فعل الأمر) } \\
& \text { حكمه : واجب (قبل النسخ) }
\end{aligned}
$$

إذا اكتمل الشروط في ثبوت الزنا -إما بإقرار أو بشهود- فالزناة حبسن في بيت يراه الحاكم

مناسبا, والحبس خاص بالنساء "والمراد بالبيوت البيوت التي يعينها ولاة الأمور لذلك. وليس المراد إمساكهن في بيوتن بل يخرجن من بيوتن إلى بيوت أخرى إلا إذا حولت بيت المسجونة إلى الوضع تحت نظر القاضي وحراسته، وقد دل على هذا المعنى قوله تعالى في آية سورة الطلاق عند ذكر العدة (لا

تخرجوهن من بيوهن) و(لا يخرجن إلا أن يأتين بفاحشة مبينة) ".

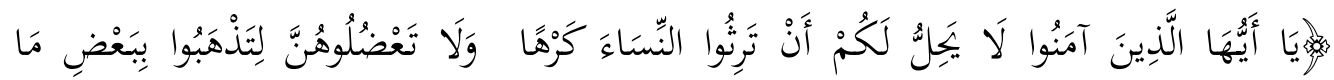

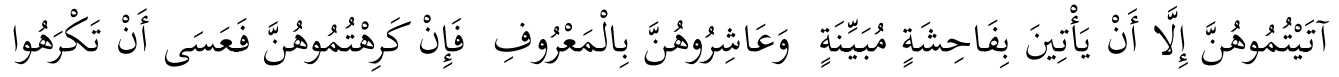

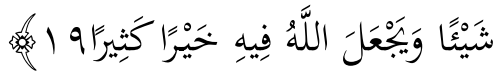

$$
\begin{aligned}
& \text { الأمر : وعاشروهن بالمعروف } \\
& \text { صيغته : صريحة (فعل الأمر) } \\
& \text { حكمه : واجب }
\end{aligned}
$$

في الآية دليل على وجوب عشرة النساء بالمعروف. "والخطاب للجميع، إذ لكل أحد عشرة،

زوجا كان أو وليا، ولكن المراد بهذا الأمر في الأغلب الأزواج, وذلك توفية حقها من المهر والنفقة، وألا يعبس في وجهها بغير ذنب، وأن يكون منطلقا في القول لا فظا ولا غليظا ولا مظهرا ميلا إلى غيرها."

$$
\text { وكذلك كل ما عده الشرع والعرف معروفا. }
$$

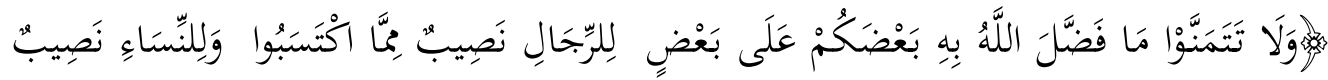

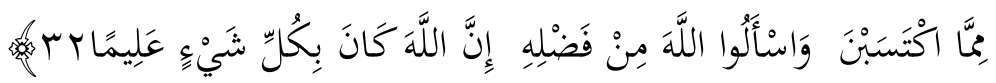

الأمر : للرجال نصيب مما اكتسبوا وللنساء نصيب مما اكتسبن

$$
\text { صيغته : غير صريجة (الجملة الخبرية) }
$$




$$
\begin{aligned}
& \text { صيغته : صريحة ( فعل الأمر) } \\
& \text { حكمه : واجب }
\end{aligned}
$$

في الأمر في الآية دليل على عدم جواز أكل أموال الناس ظلما, لأن التمني المذكور في الآية

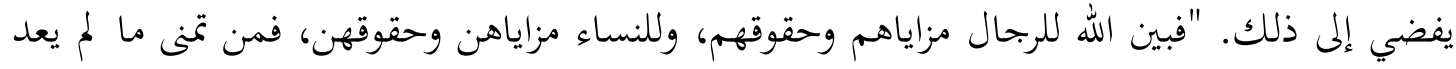

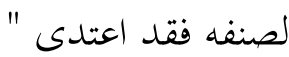

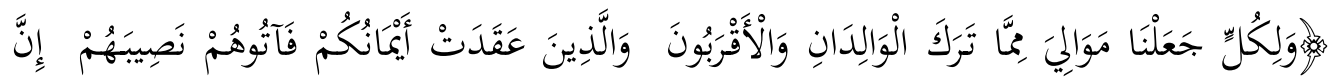

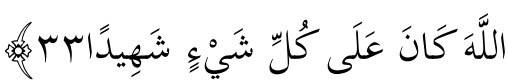

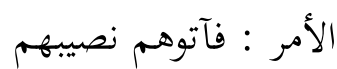

$$
\begin{aligned}
& \text { صيغته : صريحة ( فعل الأمر) } \\
& \text { حكمه : واجب (قبل النسخ) }
\end{aligned}
$$

هذا الأمر يتعلق بسبب الإرث المختلف فيه وهو المولاة والمعاقدة. والمراد بهما ما كانوا يفعلونه

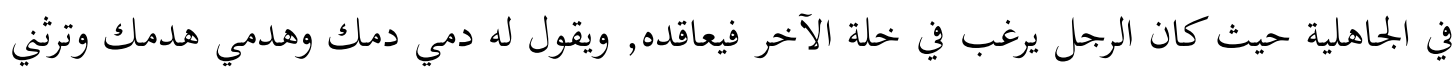

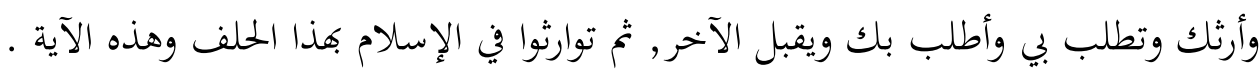

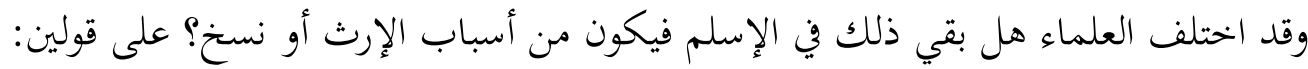

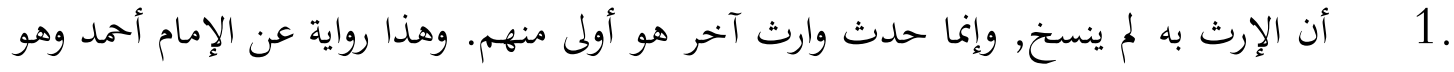

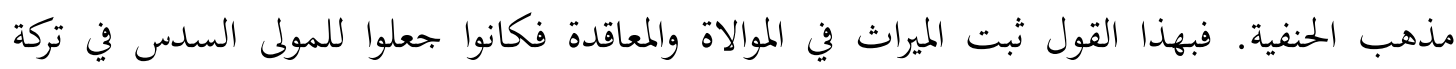

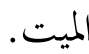

2.

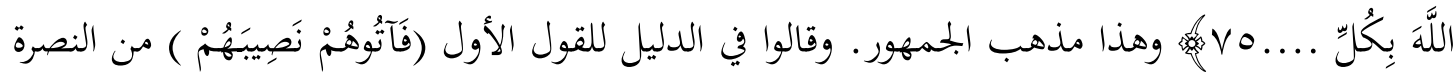
والمعونة والنصيحة والرأي .

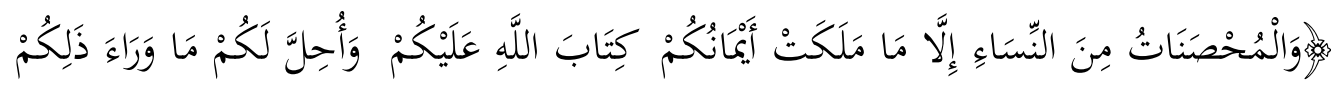

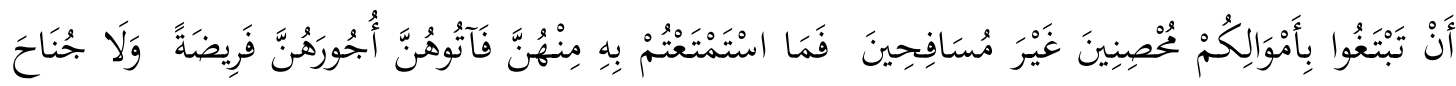

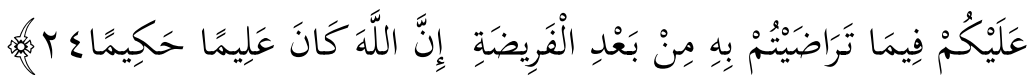
الأمر : كتاب الله عليكم

$$
\begin{aligned}
& \text { صيغته : غير صريحة (ذكر الفعل المكتوب) } \\
& \text { حكمه : واجب }
\end{aligned}
$$




\section{البصيرة: مجلة الصراهات الإهلاهية AL-BASHHIRAH: JOURNAL OF ISLAMIC STUIDES \\ Vol. 1 No. 1(2020): 180-199}

Website: https://journal.stiba.ac.id

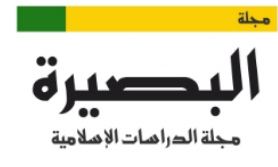

AL-BASHIRAH

فحكم ترك نكاح الخحرات من النساء في النكاح واجب, فمعنى "(كتاب الله عليكم)حرمت

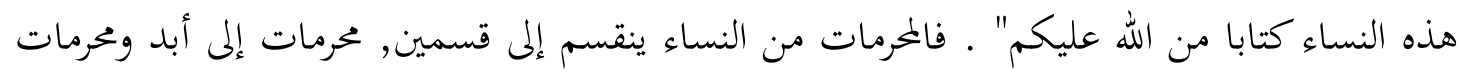

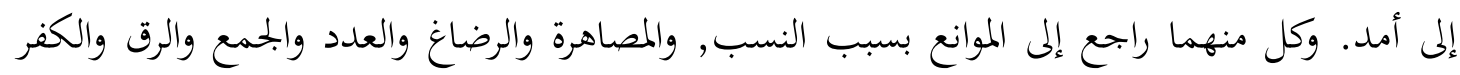

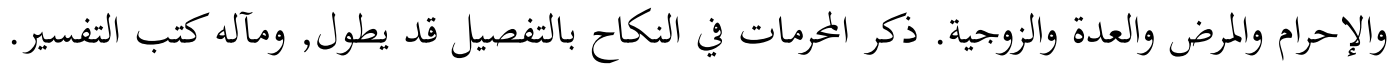
الأمر : فآتوهن أجورهن فريضة.

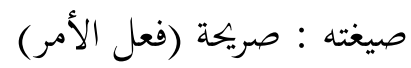

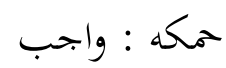

فحكم الصداق واجب كما سبق ذكره, والزايادة على دليل الوجوب أن للمرأة تبث لها المهر

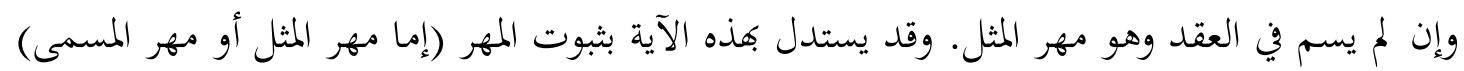

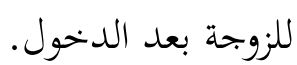

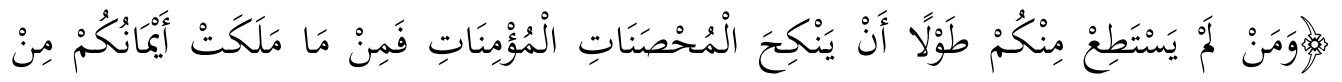

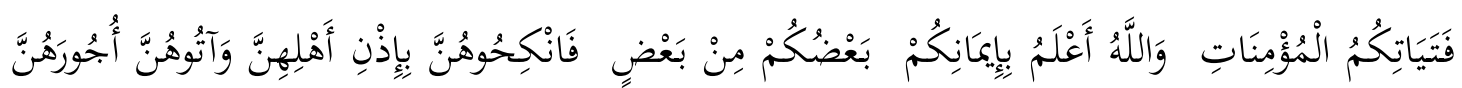

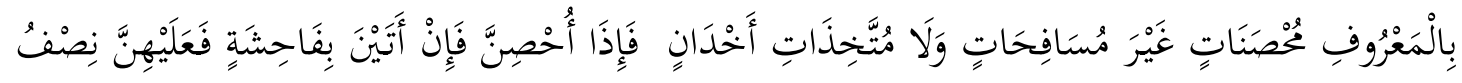

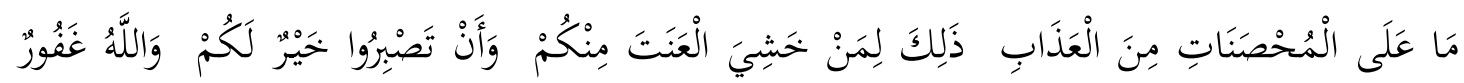

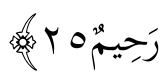
الأمر فمن ما ملكت أيمانكم من فتياتكم المؤمنات صيغنه : غير صريحة (الجملة الخبرية)

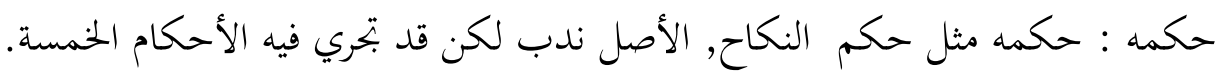

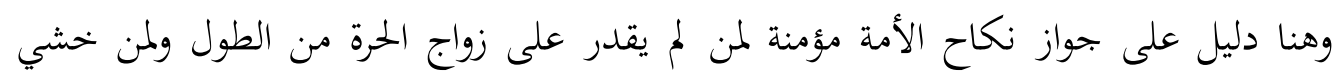

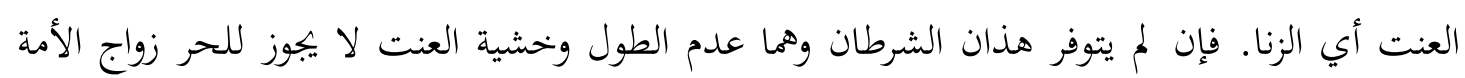
وذلك بسبب عدم الكفء واسترقاق الولد-لأن الولد يتبع الأم في الرق والعبودية. الأمر : فانكحوهن بإذن أهلهن الصيغة : صريحة (فعل الأمر) حكمه : واجب المبنة : مريكة 


\section{البصيرة: مبلة الصراهات الإهلامية AL-BASHIRAH: JOURNAL OF ISLAMIC STUIDES \\ Vol. 1 No. 1(2020): 180-199}

Website: https://journal.stiba.ac.id

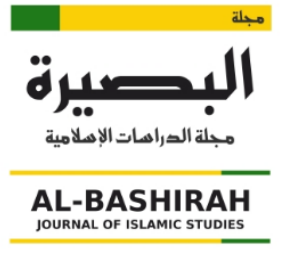

هنا دليل على جوب الإذن إلى السيد إذا أرادت الأمة الزواج, والعبد في ذلك سواء. لأن

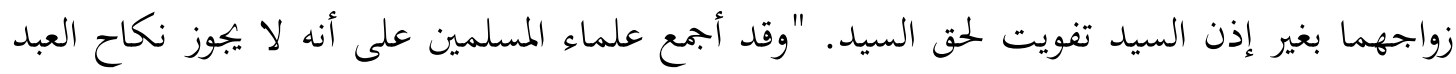
بغير إذن سيده. وقد كان ابن عمر يعد العبد بذلك زانيا ويحده " . الأمر : وءاتوهن أجورهن الصيغة : صريحة (فعل الأمر) حكمه : واجب, فحكم المهر واجب كما سبق.

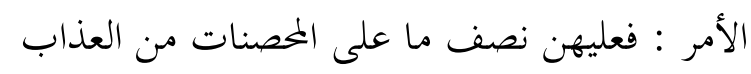

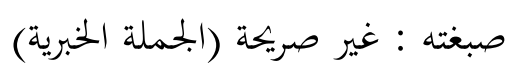
حكمه : واجب

في الآية دليل على أنّ إن زنى العبد أو الأمة وهو محصن أو محصنة فجلد جلدا بنصف جلد

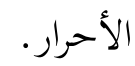
"والفائدة في نقصان حدهن أهن أضعف من الحرائر. ويقال: إذهن لا يصلن إلى مرادهن كما تصل

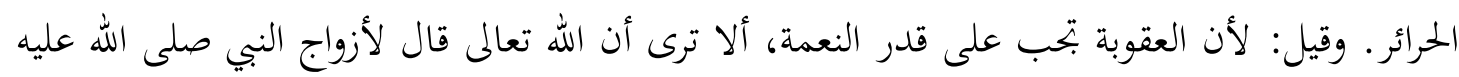

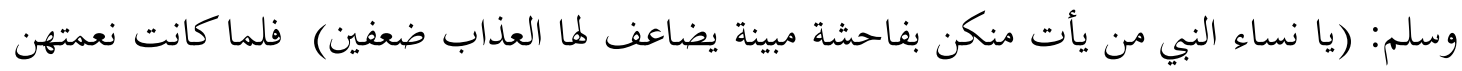

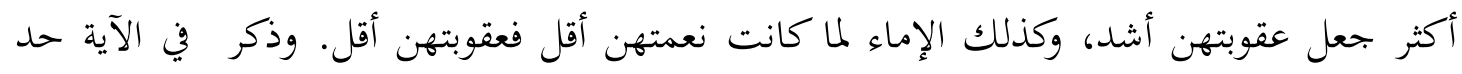

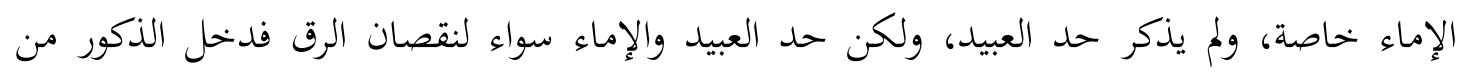
العبيد في ذلك بعلة المملوكية "

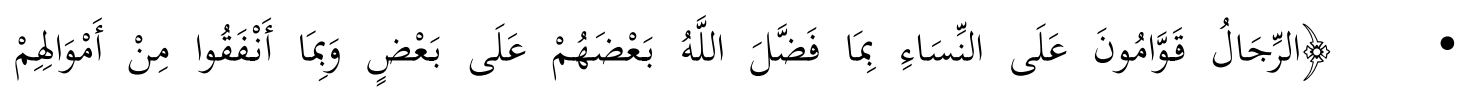

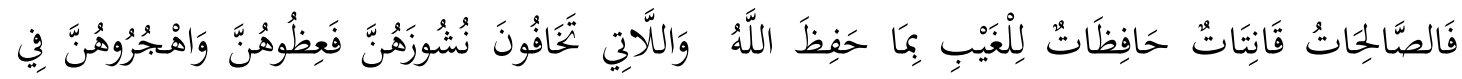

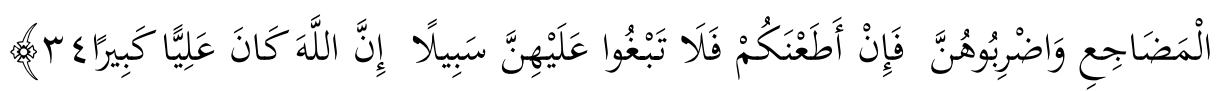
الأمر : الرجال قوامون على النساء صيغته : غير صريحة (الجملة خبرية)

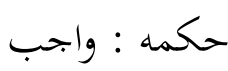
دل هذا الأمر في الآية على الرجل يقوم بأمور لا تقوم بها امرأة, وقيام الرجال على النساء هو

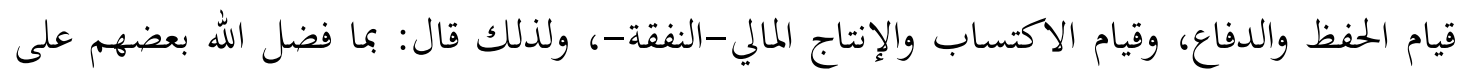

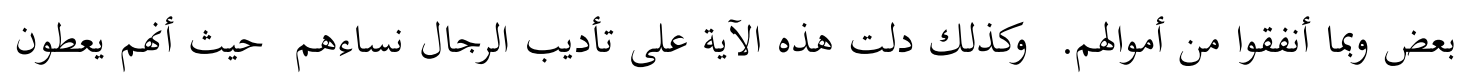
ب أو أول رفاعي , أسامة مامنج .أوامر في سورة النساء المتعلقة بأحكام الأسرة; دراسة تطبيقية 


\section{البصيرة: مبلة الصراهات الإهلاهية AL-BASHHIRAH: JOURNAL OF ISLAMIC STUIDES \\ Vol. 1 No. 1(2020): 180-199}

Website: https://journal.stiba.ac.id

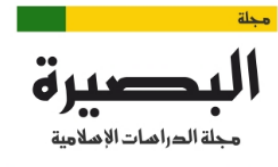

AL-BASHIRAH

حظظً من العقل ما لا يعطين. خلاصة, أن على الرجل نفقة أهله وحفظها والقيام بأمور حياتا وأن

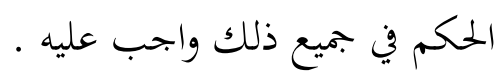

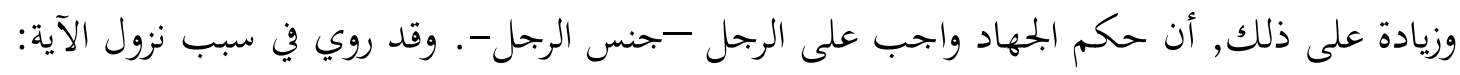

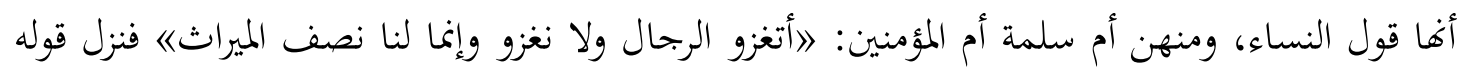

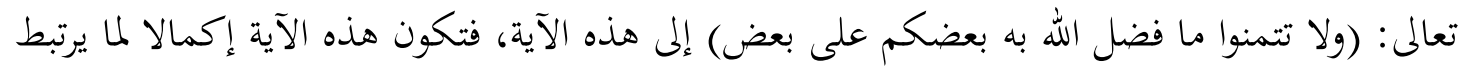

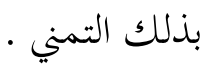
الأمر : فعظوهن واهجروهن ......واضربوهن

$$
\text { صكيغنته : صريحة (فعل الأمر) }
$$

دل هذا الأمر على حكمم نشوز المرأة والآثار المتربة عليه. قال جمهور الفقهاء: النشوز عصيان

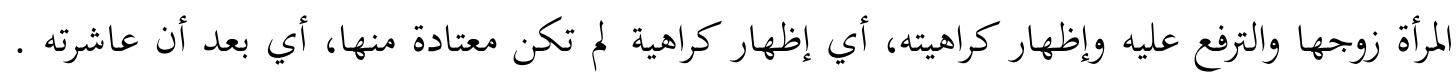

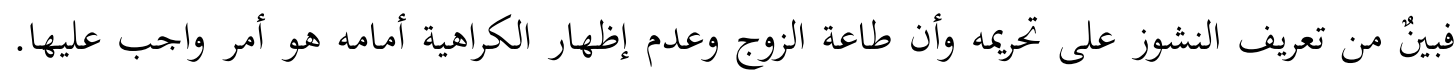

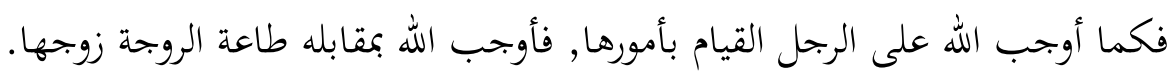

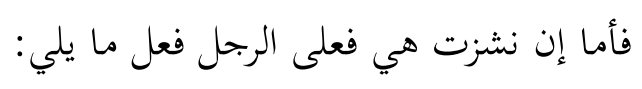
1 . 1.

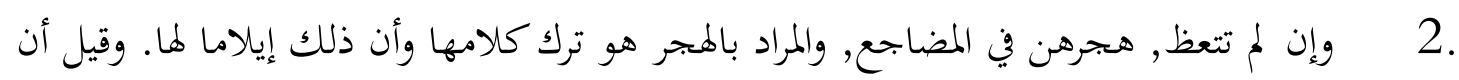

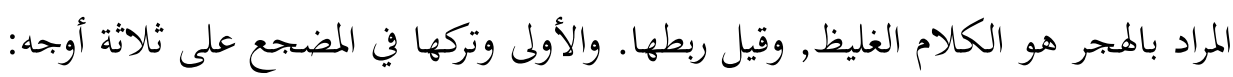

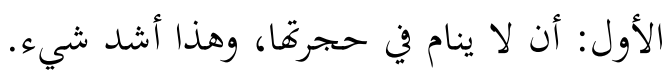

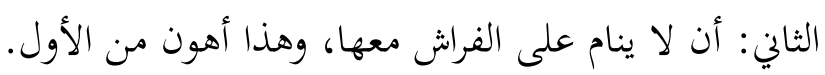

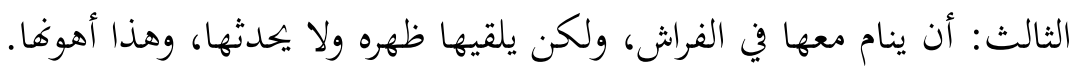

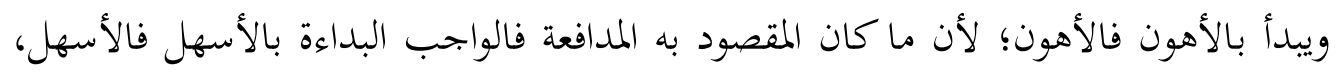

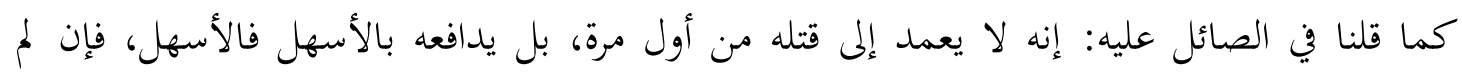
يندفع إلا بالقتل قتله.

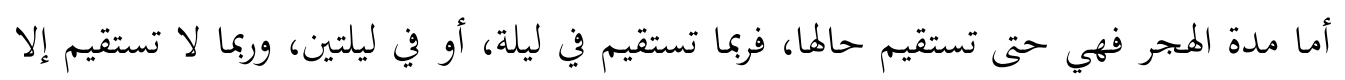

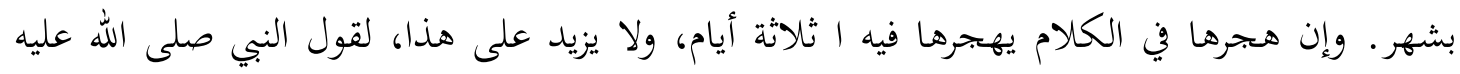




\section{البصيرة: مبلة الصراهات الإهلامية AL-BASSHIRAH: JOURNAL OF ISLAMIC STUIDES \\ Vol. 1 No. 1(2020): 180-199}

Website: https://journal.stiba.ac.id

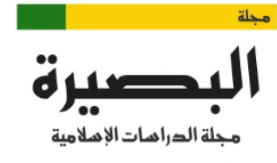

AL-BASHIRAH

وسلم: الا يحل للمسلم أن يهجر أخحاه فوق ثلاث، يلتقيان، فيعرض هذا ويعرض هذا، وخيرهما الذي يبدأ بالسلام .

3 . 3 إن لم تنته عن النشوز, فضربكن. والضرب في هذه الآية هو ضرب الأدب غير المبرح، وهو الذي لا يكسر عظما ولا يشين جارحة كاللكزة ونحوها، فإن المقصود منه الصلاح لا غير. فلا جرم إذا أدى إلى الملاكك وجب الضمان. ثم اختلف العلماء في النشوز التأديب المذكور هل هو واجب التطبيق؟ 1.

2 . 2. فيها عرف بعض الطبقات من الناس، أو بعض القبائل، فإن الناس متفاوتون في ذلك، وأهل البدو منهم لا يعدون ضرب المرأة اعتداء، ولا تعده النساء أيضا اعتداء. وقد ثبت في 》الصحيح《 أن عمر بن الخطاب قال: (كنا معشر المهاجرين قوما نغلب نساءنا فإذا الأنصار قوم تغلبهم نساؤهم فأخذ نساؤنا يتأدبن بأدب نساء الأنصار) . فإذا كان الضرب مأذونا فيه للأزواج دون ولاة الأمور، وكان سببه بجرد العصيان والكراهية دون الفاحشة، فلا جرم أنه أذن فيه لقوم لا يعدون صدوره من الأزواج إضرارا ولا عارا ولا بدعا من المعاملة في العائلة، ولا تشعر نساؤهم بمقدار غضبهم إلا بشيء من ذلك. وأن الله

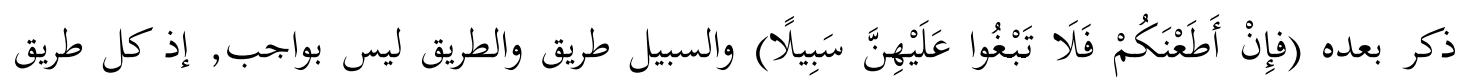
يؤدي إلى تأديبها فهو جائز غير منحصر بالآية. 3 3 الوعظ الهجر من الزوج والضرب من السلطان وهو قول عطاء وصاحب الكشاف. قال عطاء لا يضرب الزوج امرأته ولكن يغضب عليها. وقال النبي صلى الله عليه وسلم 》ولن يضرب خياركمه. ولذلك يكون المعنى واللاتي تخافون نشوزهن أي تخافون سوء مغبة نشوزهن، ويقتضي ذلك بالنسبة لولاة الأمور أن النشوز رفع إليهم بشكاية الأزواج، وأن إسناد فعظوهن على حقيقته، وأما إسناد واهجروهن في المضاجع فعلى معنى إذن الأزواج بهجراهن، وإسناد واضربوهن كما علمت . تم اختلفوا هل التأديب المذكور في النشور هو على الترتيب أم لا؟ 1 . 1 قال قوم أنه على الترتيب وهذا قول الجمهور و "الواو" المتبادر في الذهن هي للترتيب. والترتيب كما يقتضيه ترتيب ذكرها مع ظهور أنه لا يراد الجمع بين الثلاثة، والترتيب هو الأصل والمتبادر في العطف بالواو، قال سعيد بن جبير: يعظها، فإن قبلت، وإلا هجرها، فإن هي قبلت، وإلا ضربها، ونقل مثله عن علي أول رفاعي ,أسامة مامنج .أوامر في سورة النساء المتعلقة بأحكام الأسرة; دراسة تطبيقية 


\section{البصيرة: مبلة الصراهات الإهلامية AL-BASHIRAH: JOURNAL OF ISLAMIC STUIDES \\ Vol. 1 No. 1(2020): 180-199}

Website: https://journal.stiba.ac.id

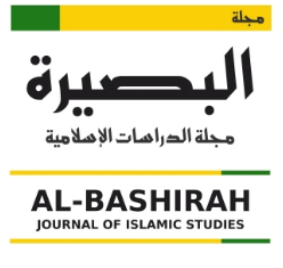

$$
2 .
$$

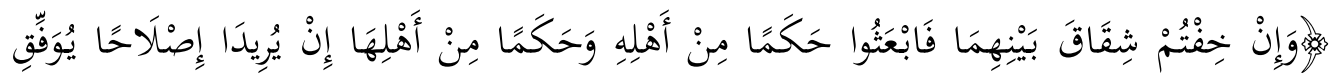

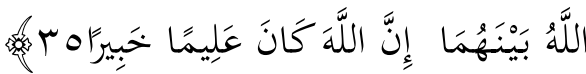

$$
\begin{aligned}
& \text { الأمر : فابعثوا حكما من أهله } \\
& \text { صيغته : صريحة (فعل الأمر) } \\
& \text { حكمه : واجب }
\end{aligned}
$$

والزوجان إذا وقعت بينهما العداوة، وخشي عليهما أن يخرجهما ذلك إلى العصيان بعث الحاكم

حكما من أهله وحكما من أهلها، مأمونين، برضى الزوجين، وتوكيلهما، بأن يجمعا إذا رأيا أو يفرقا، فما فعلا من ذلك لزمهما .

وجملة ذلك أن الزوجين إذا وقع بينهما شقاق، نظر الحاكم، فإن بان له أنه من المرأة، فهو نشوز، قد مضى حكمه، وإن بان أنه من الرجل، أسكنهما إلى جانب ثقة، يمنعه من الإضرار بها، والتعدي عليها. وكذلك إن بان من كل واحد منهما تعد، أو ادعى كل واحد منهما أن الآخر ظلمه، أسكنهما إلى جانب من يشرف عليهما ويلزهما الإنصاف، فإن لم يتهيأ ذلك، وتمادى الشر بينهما، وخيف الشقاق عليهما والعصيان، بعث الحاكم حكما من أهله وحكما من أهلها، فنظرا بينهما، وفعلا ما يريان المصلحة فيه، من جمع أو تفريق؛ لقول الله تعالى: \}و وإن خفتم شقاق بينهما فابعثوا حكما من أهله

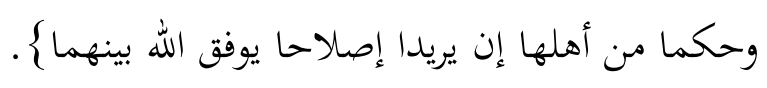$$
\text { واختلفت الرواية عن أحمد - رحمه الله -، في الحكمين : }
$$

1 ف 1 في إحدى الروايتين عنه، أفما وكيلان لهما، لا يملكان التفريق إلا بإذهما. وهذا مذهب عطاء وأحد قولي الشافعي وحكي ذلك عن الحسن وأبي حنيفة لأن البضع حقه، والمال حقها، وهما رشيدان، فلا يجوز لغيرهما التصرف فيه إلا بوكالة منهما، أو ولاية عليهما .

2 . 2 أهما حاكمان، ولمما أن يفعلا ما يريان من جمع وتفريق، بعوض وغير عوض، ولا يحتاجان إلى توكيل الزوجين ولا رضاهما. وروي نحو ذلك عن علي وابن عباس وأبي سلمة بن عبد الرحمن، والشعبي والنخعي وسعيد بن جبير ومالك والأوزاعي وإسحاق وابن المنذر لقول الله تعالى \}فابعثوا حكما من

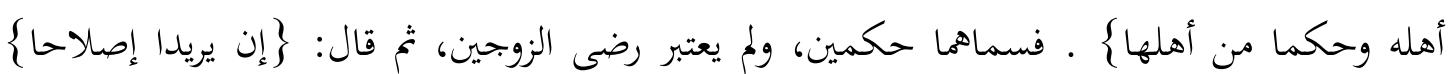
[النساء: مب] فخاطب الحكمين بذلك. 


\section{البصيرة: مبلة الصراهات الإهلامية AL-BASHHIRAH: JOURNAL OF ISLAMIC STUIDES \\ Vol. 1 No. 1(2020): 180-199}

Website: https://journal.stiba.ac.id

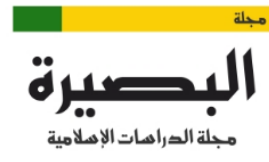

AL-BASHIRAH

إذا ثبت هذا، فإن الحكمين لا يكونان إلا عاقلين بالغين عدلين مسلمين؛ لأن هذه من شروط العدالة سواء قلنا: هما حاكمان أو وكيلان؛ لأن الوكيل إذا كان متعلقا بنظر الحاكم، لم يجز أن يكون إلا عدلا، كما لو نصب وكيلا لصبي أو مفلس، يكونان ذكرين؛ لأنه مفتقر إلى الرأي والنظر. قال القاضي: يشترط كوغما حرين. وهو مذهب الشافعي لأن العبد عنده لا تقبل شهادته، فتكون الحرية من شروط العدالة. والأولى أن يقال: إن كانا وكيلين، لم تعتبر الحرية؛ لأن توكيل العبد جائز، وإن كانا حكمين، اعتبرت الحرية؛ لأن الحاكم لا يجوز أن يكون عبدا. ويعتبر أن يكونا عالمين بالجمع والتغريق؛ لأغما يتصرفان في ذلك، فيعتبر علمهما به. والأولى أن يكونا من أهلهما؛ لأمر الله تعالى بذلك، ولأفما أشفق وأعلم بالحال، فإن كانا من غير أهلهما جاز؛ لأن أن القرابة ليست شرطا في الحكم ولا الوكالة، فكان الأمر بذلك إرشادا واستحبابا، فإن قلنا: هما وكيلان فلا يفعلان شيئا حتى يأذن الرجل لوكيله فيما يراه من طلاق أوصلح، وتأذن المرأة لوكيلها في الخلع والصلح

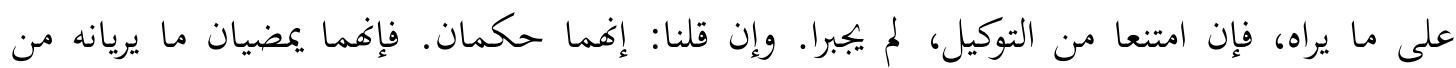
طلاق وخلع، فينفذ ذلك عليهما، رضياه أو أبياه .

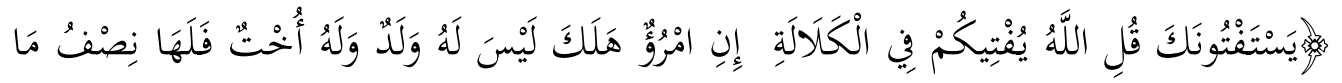

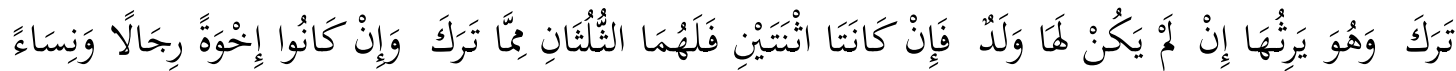

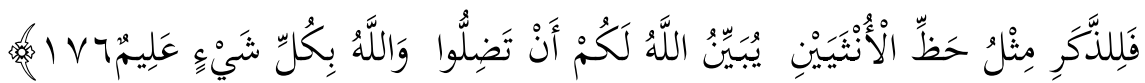
الأوامر في هذه الآية كلها على صيغة غير صريحة (الجملة الخبرية). وهي تتضمن توزيع الميراث في مسالة الكلالة, والكلالة من لا والد له ولا ولد, فبين الله في هذه الآية ميراث الإخوة والأخوات الشقيقين صرين ولأب. ومن المعلوم أن هؤلاء لا يرثون مع وجود الأصل والفرع الوارثين, ففي مسألة الكلالة انتفى الأصل والفرع فصاروا وارثين. وبيانه ما يلي : إن هلك هالك وليس له ولد ولا والد وله أخت شقيقة أو لأب فهي ترث نصف المال. فإن كانتا أختين شقيقتين أو لأب فأكثر فلهما/لهن الثلثان. وإن كانوا مختلطين رجالا ونساء فهم يقتسمون فيما بينهم بقدر الذكر مثل حظ الأنثيين

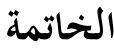

الحمد لله الذي بنعمته تتم الصالحات والصالاة والسلام على خير البريات أما بعد, هذا قد انتهي البحث وقد توصل الباحثان من خلاله نتائج فيما يلي: 


\section{البصيرة: مبلة الصراهات الإهلامية AL-BASHIRAH: JOURNAL OF ISLAMIC STUIDES \\ Vol. 1 No. 1(2020): 180-199}

Website: https://journal.stiba.ac.id

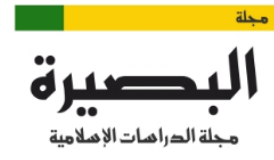

$\underset{\text { JOURAL OF ISLAMIC STUDIES }}{\text { AL-BASHIRAH }}$

$$
\begin{aligned}
& \text { 1. تعريف الأمر هو: استدعاء الفعل بالقول على وجه الاستعلاء } \\
& \text { r. الصيغة للأمر تنقسم إلى قسمين : صريحة وغير صريحة } \\
& \text { r. عدد الأوامر في أحكام الأسرة بحموعها } 17 \text { أمرا. }
\end{aligned}
$$

والتوصيات: القيام بدراسة موسوعية وموسعة شاملة لجميع نصوص القرآن وتطبيق القواعد الأصولية

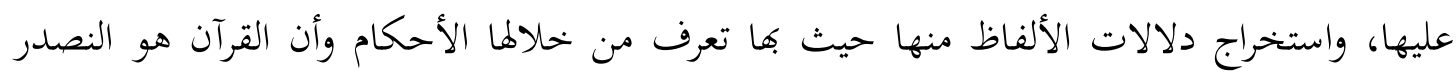
الأول للشريعة فلا بد من إعطائه الإهتمام أكثر. وصلى الله على نبينا محمد وعلى آله وصحبه وسلم.

\section{فهرس المصادر والمراجع}

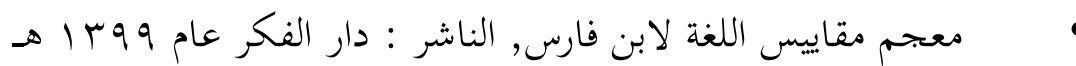

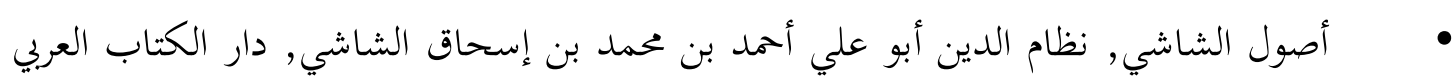

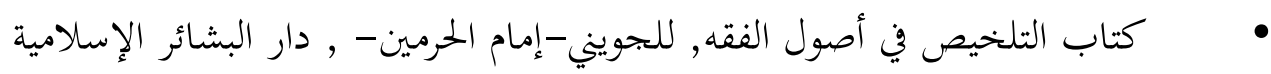

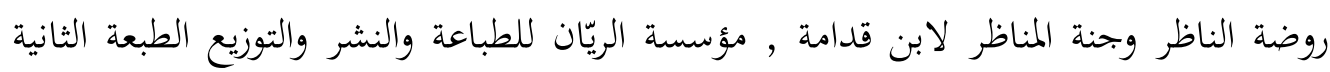

عام بr

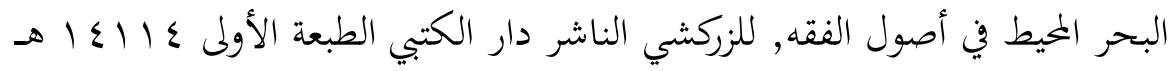

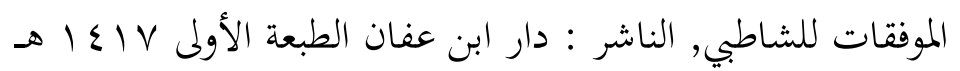

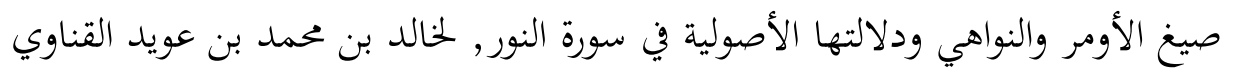

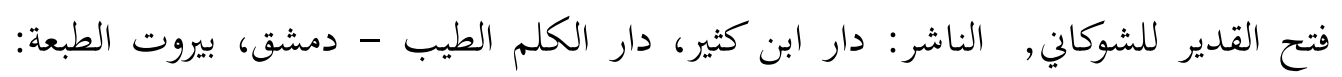

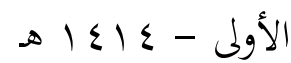

الشرح الممتع على زاد المستقنع, محمد بن صالح بن محمد العثيمين, الناشر : دار ابن الجوزي

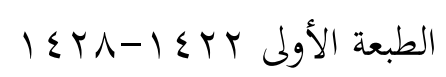

الجامع لأحكام القرآن = تفسير القرطبي, محمد بن أحمد القرطبي , الناشر: دار الكتب المصرية

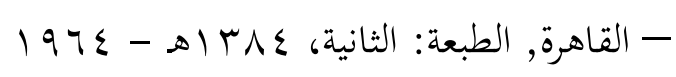

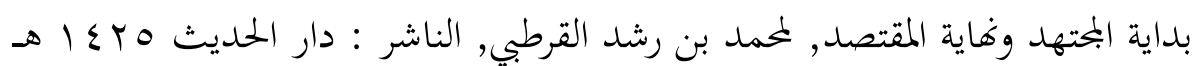




\section{البصيرة: مبلة الصراهات الإهلامية AL-BASHIRAH: JOURNAL OF ISLAMIC STUIDES \\ Vol. 1 No. 1(2020): 180-199}

Website: https://journal.stiba.ac.id

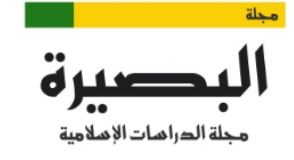

AL-BASHIRAH

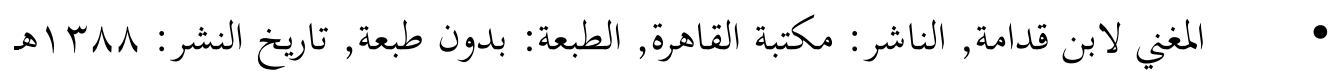

البحر المحيط في التفسير, أبو حيان محمد بن يوسف بن علي بن يوسف بن حيان أثير الدين

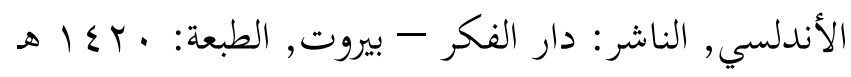

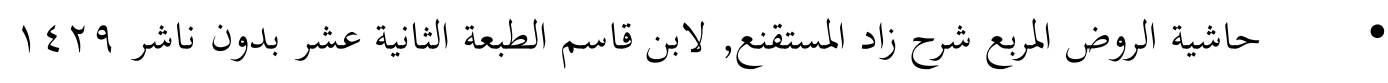

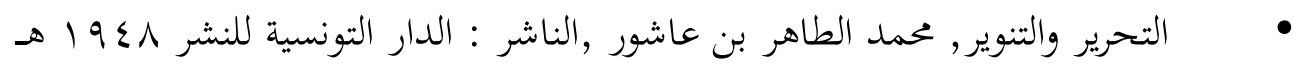

التحقيقات المرضية في المباحث الفرضية, صالح بن فوزان الفوزان, مكتبة المعارف للنشر , الطبعة

الرابعة 9 إع أمه

أصول الفقه الذي لا يسع الفقيه جهله, لعياض بن نامي بن عوض السلمي, الناشر : دار

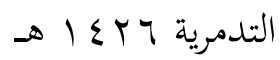

